\title{
Sustainable Choices for a Comprehensive Agricultural Sector in the Congo Basin of Central Africa
}

\author{
Ernest L. Molua ${ }^{1}$, Lamourdia Thiombiano ${ }^{2}$, Mathias F. Fonteh ${ }^{3}$, Sankung Sagnia ${ }^{4} \&$ Jean Claude Nguinguiri ${ }^{4}$ \\ ${ }^{1}$ Department of Agricultural Economics and Agribusiness, University of Buea, Cameroon, P.O. Box 63 Buea, \\ Cameroon \\ ${ }^{2}$ Food and Agriculture Organization of the United Nations, Sub-regional Office for West Africa, Accra, Ghana \\ ${ }^{3}$ Department of Agricultural Engineering, University of Dschang, Cameroon \\ ${ }^{4}$ Food and Agriculture Organization of the United Nations, Sub-regional Office for Central Africa, Libreville, \\ Gabon \\ Correspondence: Ernest L. Molua, Department of Agricultural Economics and Agribusiness, University of Buea, \\ Cameroon, P.O. Box 63 Buea, Cameroon. Tel: 237-69949-4393. E-mail: emolua@cidrcam.org
}

Received: October 30, 2014 Accepted: November 30, 2014 Online Published: December 15, 2014

doi:10.5539/sar.v4n1p67 URL: http://dx.doi.org/10.5539/sar.v4n1p67

\begin{abstract}
Agriculture in the Central African sub-region is still to fulfill its promise of creating decent employment and welfare. Climate change threatens to exacerbate this challenge. This paper specifies a model for sustainable comprehensive agricultural development in the Congo Basin and identifies options for improving livelihoods and achieving food security while addressing the global concerns of carbon sequestration and preserving biodiversity. It is suggested that the capacity of local and regional institutions be enhanced to communicate the model recommendations as part of a broad agenda in agricultural planning and decision making processes which address biodiversity management, climate change adaptation and national development priorities.
\end{abstract}

Keywords: central Africa, Congo Basin, biodiversity, climate change, sustainable agriculture

\section{Introduction}

This paper documents and develops a framework for transforming Central African agriculture in the advent of environmental degradation, rising demand for food whilst conserving biodiversity as well as climate change. The changing climate is the Achilles heel to African agriculture. Climate change, manifesting as increase in global average surface temperature as well as in altered precipitation patterns, is an increasingly serious threat to the quality of life, sustained economic growth and poverty reduction and political stability especially in ecological resource dependent communities (FAO, 2012; Toulmin, 2009; IPCC, 2007). According to the FAO (2010), climate change poses threats to agriculture, including production stability and incomes with the plausibility of reinforcing food insecurity and increased disaster related to either floods or droughts. Climate variables being key determinants of biophysical characteristics of ecosystems, communities and species, not only affect species attributes and ecological interactions, but ecosystem processes as well (FAO, 2012; Brown \& Corbera, 2003). The increasingly unpredictable and erratic nature of weather systems in rural Africa has, therefore, placed an extra burden on food security and rural livelihoods. UNEP notes that in addition to directly impacting on yields through changes in weather patterns and disease, land use change will be important, particularly with recent commitment to reduction of emissions from deforestation and degradation within the post Kyoto framework.

The Congo Basin lying astride the Equator in west-central Africa, which is home to the second largest rainforest in the world - almost 2 million $\mathrm{km}^{2}$ - and extending continuously from about $4^{\circ} \mathrm{N}$ to about $5^{\circ} \mathrm{S}$, has an equatorial climate that is coextensive with its dense evergreen tropical forest. As shown in figure 1, this hydrographic basin of the River Congo includes almost the whole of the Republic of the Congo (RC), the Democratic Republic of Congo (DRC), the Central African Republic (CAR), Cameroon, Gabon and Equatorial Guinea. It is a major transboundary natural resource pool spanning approximately 200 million hectares, with about 65 million people living inside or at the margins. Subsistence small-scale slash-and-burn shifting cultivation is the dominant economic activity and farm practice of the inhabitants (Sonwa et al., 2011; Bellassen \& Glitz, 2008; Zhang et al., 2002). Poverty and underdevelopment are significant (de Wasseige et al., 2009). 
About $73 \%$ of the population in the basin is found in the CAR and DRC which are classified among the lowest income countries in the world (Nkem et al., 2010). Climate change is already impacting economic growth in the basin and constrains countries from realizing targets set in the millennium development goals (Justice et al., 2001). The vulnerability of the region is underscored in livelihoods significantly dependent on climate-sensitive sectors like agriculture, fisheries, pastoral practices and forests (Awono et al., 2010; Brown \& Lapuyade, 2001).

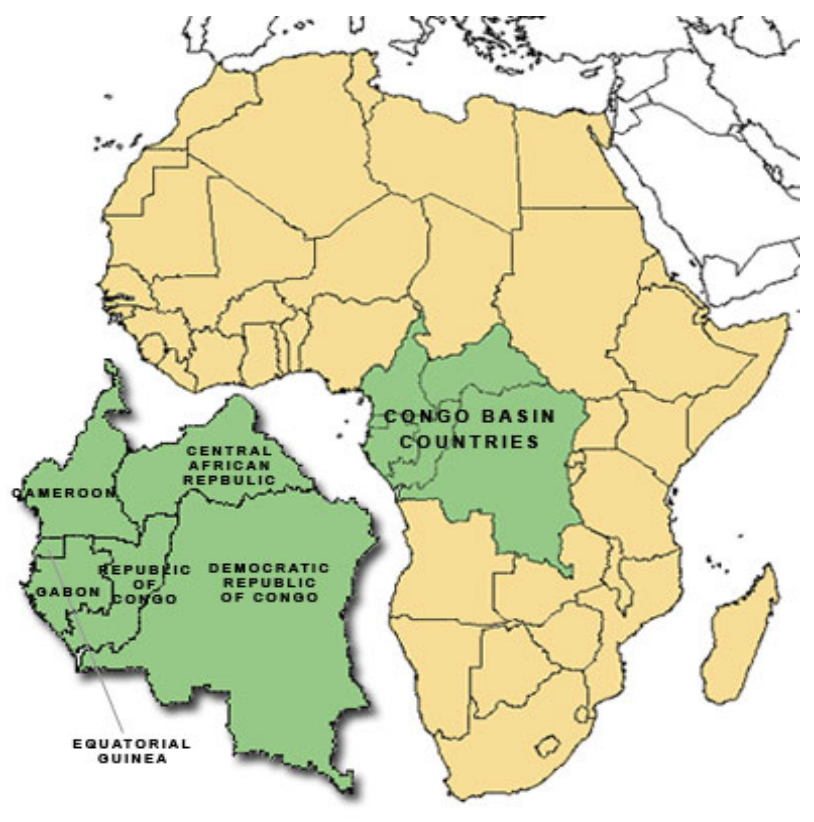

Figure 1. Congo Basin countries

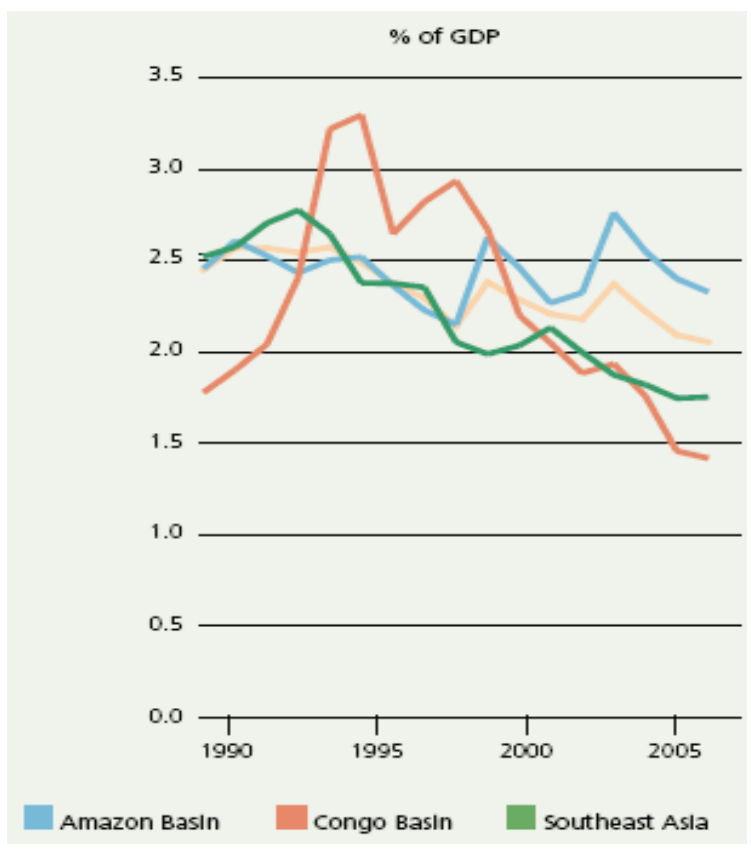

Figure 2. Forestry's contribution to GDP in the three rainforest basins, 1990-2006

Gauging the importance of the Congo Basin Forest (CBF) relative to other significant forest repositories, the provisions from forestry activities, wood industries and the pulp and paper industry together contributed on average $2 \%$ to the GDP in all three important rainforest basins of the world (Figure 2). The contribution of the forestry sector to GDP is decreasing as other sectors of the economy grow faster. In the Congo Basin, more than $80 \%$ of the value added comes from forestry and logging, and only $1 \%$ from the pulp and paper industry, while in Southeast Asia, less than $40 \%$ is attributed to forestry and logging, with an additional $34 \%$ from the wood industry and 27\% from the pulp and paper industry (FAO, 2011).

Human induced climate change, as well as a growing human population and continued economic expansion will further exacerbate ecosystem degradation and biodiversity loss - with the Congo Basin expected to suffer significant losses. This loss forms a major barrier to sustainable development in these regions and around the world. What is important about the unfolding climate change challenge in relation to ecological assets is that agriculture dependent on the exploitation of new forest land will be greatly impacted by climate change (Justice et al., 2001) and will require substantial adaptation efforts (Campbell, 2009). At the same time, the agricultural sector being responsible for a significant amount of greenhouse gas emissions, has an important potential role in climate change mitigation (Bonan, 2008; Canadell \& Raupach, 2008; Dobbs \& Pretty, 2004). Reviewing sustainable choices for African agriculture therefore needs to be approached within a matrix of interacting factors that contribute to environmental degradation and a spiralling dynamic of socio-economic and political consequences.

The potentials of the CBF has contributed to stirring debates whether Reducing Emissions from Deforestation and Forest Degradation while promoting conservation, sustainable management of forests and enhancement of forest carbon stocks (REDD+) under the United Nations Framework for Climate Change (UNFCCC) (Note 1), could create a financial value for the carbon stored in forests, thus offering incentives for developing countries such as in the $\mathrm{CBF}$ to reduce emissions from forested lands and invest in low-carbon paths to sustainable development (Harvey et al., 2010; Bryan et al., 2008). The challenge therefore is not only to promote adaptation 
to climate change impacts in the $\mathrm{CBF}$, but to explore means for its continuous productivity without jeopardizing the integrity of the forests to ensure the continuous provisioning of ecosystem goods and services vital for household livelihoods, national development and economic growth of the region. The goal of this paper is therefore to elucidate through a scooping review, sustainable choices for agriculture in the CBF, and specifically present and discuss the plausibility of a comprehensive model for the agricultural sector for the sub-region in a scenario of changing local and global conditions. The paper thus proceeds as follows. Section 2 presents a brief description of the competing environmental and socioeconomic developments in the Congo Basin. We then develop a conceptual framework for options in a Comprehensive Agricultural Sector Model. Section 4 of the paper highlights some policy perspectives and capacity building strategies for a comprehensive agricultural sector development.

\section{Competing Environmental and Socioeconomic Developments in the Congo Basin}

The CBF being host to a wealth of biodiversity and the breadbasket to millions of people not only plays a critical role for global biodiversity conservation (Kamdem-Toham et al., 2003), but also provides a wide range of environmental services which include regulatory functions- support to economic activities and human wellbeing (e.g. climate regulation, regulation of the hydrologic cycle, protection against soil erosion, carbon sequestration and recycling organic matter and human waste) (Asaah et al., 2011; Matthews et al., 2002; Kotto-Same et al., 1997). Nkem et al. (2010) reveals a range of productive functions- provision of basic resources (e.g. building materials, fuel wood, non-timber food products and game, medicinal plants, genetic resources). According to Sonwa et al. (2011), physical support (provision of space and required substrate for habitat, farming zones, recreational sites, conserved natural spaces), and informational functions i.e. provision of aesthetic, cultural and scientific benefits (e.g. source of cultural and artistic inspiration, spiritual information, historic, scientific and educational information) are principal functions of the CBF to its host communities. Hence, besides supplying game and wood, regulating the local climate and the flow of water (Note 2), protecting and enriching soils, controlling pests and diseases and safeguarding water quality, the range of benefits provided by the CBF extends well beyond the African continent, especially in global climate regulation. For instance, the CBF help regulate the climate by sequestering and storing 10 billion to 30 billion metric tons of carbon (Feddema et al., 2005; Kamdem-Toham et al., 2003). Bellassen and Glitz (2008) and Zhang et al. (2002) note significant potentials of about 25-30 million tons of carbon stocks are locked in the vegetation in the CBF, and more than twice as much in the soil and litter sinks.

Table 1. Trends in forest area in the three rainforest basins, 1990-2010

\begin{tabular}{cccccccc}
\hline & \multicolumn{3}{c}{ Area } & \multicolumn{2}{c}{ Annual Change } & \multicolumn{2}{c}{ Annual change rate } \\
Region & & $(1000 \mathrm{ha})$ & \multicolumn{2}{c}{$\begin{array}{c}(1000 \mathrm{ha}) \\
(\%)\end{array}$} \\
& 1990 & 2000 & 2010 & $1990-2000$ & $2000-2010$ & $1990-2000$ & $2000-2010$ \\
\hline $\begin{array}{c}\text { Amazon } \\
\text { Basin }\end{array}$ & 874321 & 835847 & 799394 & -3847 & -3645 & -0.45 & -0.44 \\
$\begin{array}{c}\text { Congo } \\
\text { Basin }\end{array}$ & 316078 & 308864 & 301807 & -721 & -706 & -0.23 & -0.23 \\
$\begin{array}{c}\text { Southeast } \\
\text { Asia }\end{array}$ & 277817 & 252324 & 242048 & -2549 & -1028 & -0.96 & -0.41 \\
$\begin{array}{c}\text { Rainforest } \\
\text { Basins } \\
\text { World }\end{array}$ & 1468216 & 1397035 & 1343249 & -7118 & -5379 & -0.50 & -0.39 \\
\hline
\end{tabular}

Source: FAO, 2011.

However, over the past 30 years the CBF ecosystems have been extensively modified to meet the rapidly growing demands for food, fresh water, timber fibre and fuel. These forests are vulnerable to slash-and-burn farming, and logging (Ezzine de Blas et al., 2009; Kotto-Same et al., 1997), which release substantial carbon stocks and thus contribute to global climate change (Feddema et al., 2005). The net change in forest area over time - sum of all negative changes due to deforestation and natural disasters, and all positive changes due to afforestation and natural expansion of forests - is shown in Table 1. In the period of 1990-2000 the CBF forest 
area declined by 721,000 ha with an annual decline of $0.23 \%$. This compares favourably to the rainforest average that declined by $0.5 \%$. While the Amazon and Southeast Asian forest basins had higher rates of forest area decline, the degradation of the CBF is significantly due to unsustainable slash-and-burn agricultural practices (FAO, 2011).

The typical rainfed slash-and-burn shifting farming system in the CBF is highly vulnerable to climate change (Thornton et al., 2011; Zhang et al., 2002). Projections of temperature rise indicate that climate change may reduce crop yields by $20 \%$ by mid twenty-first century, with food prices of some grain staples like maize and rice rising between $30-100 \%$ (Nelson et al., 2010). Increasing frequencies of heat stress, drought and flooding events, proliferation of pests and diseases will exacerbate these impacts with extreme price and yield volatility (Note 3).

Although the Congo Basin's overall annual carbon dioxide emissions are low, deforestation and degradation account for 90\% (20-60 million tons per year) of its emissions (Kamdem-Toham et al., 2003; Justice et al., 2001; Kotto-Same et al., 1997). Some evidence suggests that selective logging accounts for $25-50 \%$ of the region's carbon losses (Sonwa et al., 2011; Justice et al., 2001), and also helps to open up new forest areas for activities such as slash-and-burn farming that are likely to accelerate carbon and biodiversity losses (Duveiller et al., 2008; Kamdem-Toham et al., 2003). Therefore, the continued destruction and degradation of the forests hampers the provision of environmental services, undermines the global response to climate change, and reduces the local capacity to adapt to climate change impacts (Ravindranath, 2007). It is for these reasons that there is global concern about stopping deforestation and reducing the degradation of forests.

There is no doubt that for food security to be assured and poverty alleviated for the rapidly growing population in the $\mathrm{CBF}$, agriculture must be intensified to increase agricultural productivity. The question is how this can be done taking into account the environmental concerns of preserving the forest. This requires a model of agriculture now defined by FAO (2010) as climate-smart agriculture. This is agriculture which sustainably increases productivity, is resilient (adaptation function), reduces or removes green house gases (mitigation), and enhances the achievement of national food security and developmental goals (see Koohafkan et al., 2012; Thiombiano et al., 2012). Many climate-smart agricultural techniques already exist and simply need to be repackaged for better adoption by farming community. Such techniques which include soil and water management, pest control, conservation of genetic resources, and combining crops, trees, livestock, fisheries, etc., may be integrated into production systems which offer "multiple wins" for adaptation and mitigation. However, despite these potentials three key challenges emerge, requiring a comprehensive agricultural sector development agenda:

a. Scaling-up proven biodiversity-friendly and climate-smart agricultural practices;

b. Lack of willingness by organisations with biodiversity expertise to engage with agribusinesses; and,

c. Dearth of local biodiversity expertise as companies with biodiversity commitments find it difficult to locate local partners to assist their work.

\section{Options for a Comprehensive Agricultural Sector Model}

There are many proposals on how to achieve a sustainable agriculture that provides enough food and ecosystem services for present and future generations in an era of climate change and increasing environmental degradation (e.g. Thiombiano et al., 2012). Agricultural systems that capture the diversity of ecological, socio-economic and political contexts in the Congo Basin must be one that embodies the techniques and practices of agroforestry, conservation agriculture, watershed protection through riparian forest buffer and integrated with markets, which not only contributes to sustainable production but also ensures producers find concrete opportunities in value chains which enhances both the profitability and decency of agriculture as a guarantor for employment.

Agroforestry (Note 4) has been shown to tackle the challenges of ensuring food security, promoting mitigation, reducing the vulnerability and increasing the adaptability of agricultural systems to climate change (Bonan, 2008). Schroth et al. (2004) and Donald (2004) note that specific types of agroforestry systems, for example, have potential to foster wild biodiversity by providing corridors between protected areas, providing habitat conducive to wild fauna and flora, and reducing human pressure on protected areas. Trees in the farming system especially fruit trees, may help increase farm incomes and diversify production and thus spread risk against agricultural production or market failures. Trees and shrubs have significant potentials to diminish the effects of extreme weather events, such as heavy rains, droughts and wind storms. They prevent erosion, stabilize soils, raise infiltration rates and halt land degradation (Sawadogo, 2011; Valentin et al., 2002). They can enrich biodiversity in the landscape and increase ecosystem stability. Studies indicate that agroforestry systems in 
Africa have increased maize yields by 1.3 and 1.6 tons per hectare per year (Sileshi et al., 2008). Asaah et al. (2011) further demonstrate how multifunctional agroforestry in Cameroon delivers social, economic and environmental sustainability and raises poor people out of poverty, malnutrition and environmental degradation. Agroforestry is therefore important both for climate change mitigation as well as for adaptation through reducing vulnerability, diversifying income sources, improving livelihoods and building the capacity of smallholders to adapt to climate change.

While tree-based agricultural systems contribute to biodiversity conservation (Kamdem-Toham et al., 2003), long-rotation tree-based agricultural systems store more carbon than any other land use type except the natural forest (ICRAF, 2002a; Kotto-Same et al., 1997). In the Congo basin, mature cocoa agro-forests were found to maintain about $60 \%$ of the carbon stock of primary forests (ICRAF, 2002b). Lewis et al. (2002) shows that multi-strata agro-forests have the highest biodiversity after primary forests followed by improved fallows with tree crops. Improved tree fallow consists of planting tree legumes, whose roots combine with microorganisms to fix atmospheric nitrogen. The use of improved crops too, within the agroforests provides additional economic and environmental benefits. For instance, reductions in carbon dioxide emissions could come from substitution of nitrogen fertilizer with the use of nitrogen fixing crops such as soybeans. In Southern Africa, soybean was identified as the crop with a potential to address the need for diversifying the cropping systems, which could assist in overcoming the pervading soil fertility constraints and could provide smallholder farmers with an opportunity to earn income while also addressing the nutritional security of households (Giller et al., 2011). In Zimbabwe, for instance, the rotational benefits of soybean often lead to a doubling of maize yields - due to breaking the continuous cultivation of maize and the addition of nitrogen to the soil from the residues of soybean that gives a small but significant improvement in soil fertility (Mpepereki, 2000).

Conservation agriculture (CA) which encompasses farming practices that have three key characteristics: minimal mechanical soil disturbance (i.e. no tillage and direct seeding), permanent soil cover (e.g. use of straw and/or other crop residues including cover crops), and rotations or sequences and associations of crops including trees which include nitrogen-fixing legumes; provides much promise within larger agroforests (Silici et al., 2011; Kassam et al., 2009). CA thus attempts to increase productivity by improving the management of agriculture, using available resources and technologies in the different agro-ecological zones (Marongwe et al., 2011; Owenya et al., 2011). In dry conditions, the protective soil cover of leaves, stems and stalks from the previous crop shields the soil surface from heat, wind and rain, keeps the soil cooler and reduces moisture losses by evaporation. In drier conditions, it reduces crop water requirements, makes better use of soil water and facilitates deeper rooting of crops. In extremely wet conditions, CA facilitates rain water infiltration, reducing soil erosion and the risk of downstream flooding. Conservation agriculture also protects crops from extreme temperatures. Crop rotation over several seasons also minimises the outbreak of pests and diseases. Conservation Agriculture thus contributes to adaptation to climate change by reducing crop vulnerability. In addition, it sequesters carbon in soil (Zhang et al., 2002), as avoidance of tillage minimises occurrence of net losses of carbon dioxide by microbial respiration and oxidation of the soil organic matter and builds soil structure and biopores through soil biota and roots (Kotto-Same et al., 1997). The economic worthiness of agroforestry and conservation agriculture projects is documented in Pretty et al. (2011) to benefit farmers and their families and improvements on approximately 12.75 million ha. They also highlight the potential for increased yields per hectare by combining the use of new and improved varieties and new agronomic - agroecological management.

Protecting watershed is important for the CBF. Huge expanse of forests along river margins provide valuable ecosystem services by protecting water quality and providing resources to aquatic organisms. Deforestation of riparian forests can have negative impacts on the health and well-being of rural communities who rely on these aquatic resources. Forest buffer adjacent to the plethora of streams, lakes, ponds and other wetlands intercepts sediments, nutrients, pesticides and other materials in surface runoff and hence reduces the amount of pollution from adjacent land. The buffer provides food and cover for wildlife, provides corridors for the movement of wildlife, helps lower water temperatures, the roots of trees increases the resistance of the banks to erosion, and the vegetation closest to say a stream provides litter fall and large woody debris which are important to aquatic organisms. These buffers therefore contribute in carbon sequestration, preserving biodiversity and protecting the watershed. In degraded landscapes these buffers should be established while in secondary and primary forests, the buffer should be left during land clearing.

Production is not complete until the good gets to the final consumer. Access to market opportunities, support infrastructure (e.g. storage, packaging, retail facilities and information technology) and other trade-related interventions are therefore important for producers in the CBF to succeed in their production operation. This should be developed simultaneously with regional value chains for staple agricultural commodities, e.g. plantain, 
banana, cassava, maize and citrus fruits and later extend to other strategic agricultural commodities, especially those identified by the AU Food Security Summit in Abuja (e.g. rice, cotton, oil palm, legumes, maize, beef, dairy, poultry and fisheries products as strategic commodities at the continental level, and cassava, sorghum and millet at sub-regional level) being essential for African countries to enhance their agricultural transformation and global competitiveness (AU, 2006). Market access and value chain development is essential for Congo basin countries not only to enhance their agricultural transformation and global competitiveness, but also to promote growth of production and incomes, for equity and farmer welfare. Market value chain development has the twin potential of improving the product quantities, qualities, delivery times and prices of agricultural tradable in the Congo basin. Increasing market assess and ensuring commodity value chains, market power can be enhanced through reenergizing and promoting farmer market cooperatives that sell produce to middlemen and processors at rewarding prices which uphold the dignity of their employment in the agricultural sector. There is thus need to replicate projects within the basin (e.g. Asaah et al., 2011) that train farmers to become processors, value-adders, traders, fabricators of processing equipment and as active agents in the entire production-marketing chain.

Currently, there is little value addition and transformation of agricultural produce in the region. The largely raw commodities produced are essentially inputs into a vertical commodity chain, with the raw commodity only a small proportion of the value of the final product. Farmers thus receive less than optimal returns to their farming effort largely because of processing constraints and lack of market power in selling their produce. The model for countries in the Congo forest basin is to develop specific commodity value chains which link the farmer to the consumer. The typical value chain for agricultural commodity transaction include farm inputs, farm gate sale, local transport, local sale, processing, regional transport and regional sale, with value added at each transaction point. While this includes multi-sectoral effort on research and development, input suppliers, production, processing, marketing and finance; countries in the region may actually begin by identifying and removing all major constraints to achieving competitiveness, and to also ensure equitable returns for producers and those who operate within the local and export food distribution systems.

Figure 3 is a schema for a plausible comprehensive recursive rationalized agricultural sector model. Its central focus is a farming system that is ecologically friendly and environmentally sustainable, receiving the necessary contributions from agricultural research (Note 5), extension and capacity development on prescribed ecologically and climate-smart agricultural practices. Agroforestry, conservation agriculture and watershed protection are at the heart of the model providing opportunities for intensification and environmental protection. The essential components of farm finance, market access and benefits from value chain addition provide incentives for farmers to adopt technologies that protect farm forests. As noted in Figure 3, while it is important to manage land and water, optimizing their use and minimizing the environmental impact, revitalizing crop plant and animal health management will guarantee the maximization of crops' and animals' full potential yields, and increase their production limits through more efficient physiology. Yerima (2011) observes that for sustainable use and conservation of biodiversity there is need to harness and apply science and technology, through investments in research and innovation to generate technologies for conservation and sustainable use of biodiversity.

These efforts and other land and water management measures will guide the production of more food on less land in more sustainable ways within AFS, CA and WP sub-systems. Combining AFS, CA and WP contributes to mitigation and low emission development strategy in three ways:

- $\quad$ Avoiding deforestation and conversion of grasslands and wetlands;

- Increasing the storage of carbon in vegetation and soil;

- $\quad$ Reducing current, and avoiding future, increases in emissions from nitrous oxide - from fertilizer use and soil organic matter breakdown. 


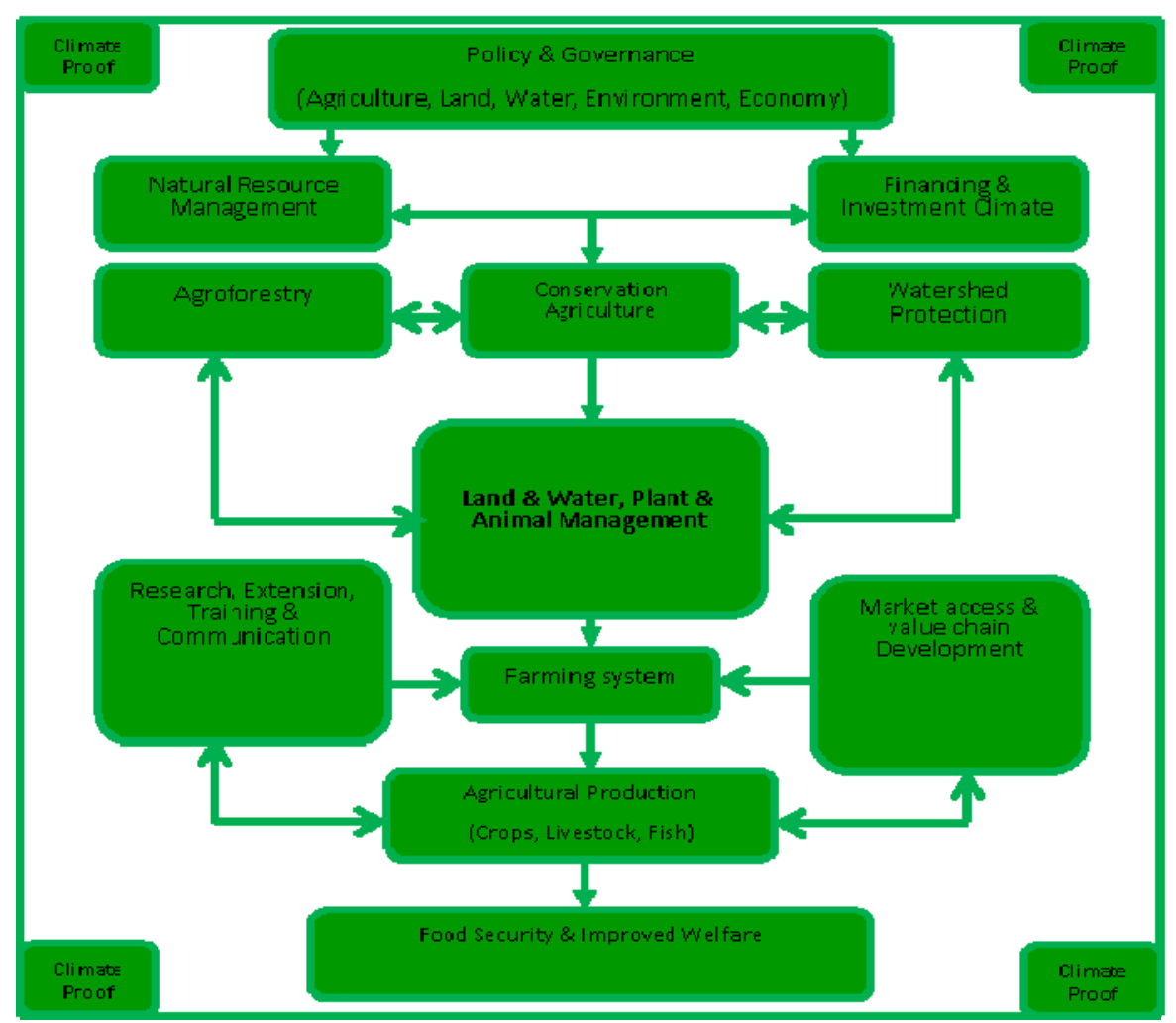

Figure 3. Congo basin comprehensive agricultural sector model

\section{Policy Perspective and Capacity Building for a Comprehensive Agriculture}

Where climate-proof sustainable agriculture have worked as noted in Ajayi et al. (2011), Asaah et al. (2011), Brummett and Jamu (2011), FAO (2009) and Pretty et al. (2011), the challenge is thus to spread effective processes and lessons to millions of generally small farmers. Enhancing agricultural practices that protect biodiversity in the Congo basin forest communities will require novel capacity building approaches. For some successful projects and programmes for sustainable intensification in other parts of the continent, Pretty et al (2011) report some lessons for scaling up and spreading to include: (i) science and farmer inputs into technologies and practices that combine crops-animals with agroecological and agronomic management; (ii) creation of novel social infrastructure that builds trust among individuals and agencies; (iii) improvement of farmer knowledge and capacity through the use of farmer field schools and modern information and communication technologies; (iv) engagement with the private sector for supply of goods and services; (v) a focus on women's educational, microfinance and agricultural technology needs; (vi) ensuring the availability of microfinance and rural banking; and (vii) ensuring public sector support for agriculture. Amongst these, functional research-extension architecture is a primordial launch-pad for improvements in agronomic practices (Brummett \& Jamu, 2011; Liebenehm et al., 2011; Wabungu et al., 2011; Kristjanson et al., 2009). However, with the decline of public extension services community-based process of education, experimentation, adaptation and adoption of improved techniques is used to address both the knowledge-intensive and context-specific challenges. Settle and Garba (2011) reports on how farmer field school (FFS) approach can be used to successfully catalyse improved agronomic practices, better decision-making skills and diversification of 116,000 smallholder farms in Niger River basins in West Africa.

Policy is overarching the architecture of our model prescriptions. This highlights the principal role of governments to provide the enabling environment and conditions for the interaction of the constituent sub-sectors of agriculture. Government actions will have to foster training, market information, land tenure policies, provision of finance and credit facilities, fiscal policies, industry policies and marketing infrastructure and agricultural extension. Styger et al. (2011) demonstrated the plausibility with the system of rice intensification (SRI) amongst resource-limited smallholders. With SRI, the implementation processes and approaches changed with each year and depended on (i) the technical adaptation of SRI practices, (ii) farmers' and technicians' know-how of the SRI technical requirements, (iii) collaboration with the government extension 
and research agencies and (iv) the funding level. SRI practices have induced a dramatic shift in the perception and understanding of how to achieve sustainable and productive rice cropping systems, stimulating farmers and technicians to initiate a series of innovations inspired by the SRI system. Therefore, the premise of a renewed agricultural policy should be that of realizing more returns to agriculture from less land use, i.e. a significant means of jointly achieving mitigation and food production in agriculture, assuming that the resulting spared land sequesters more carbon or emits fewer greenhouse gases than farmland (FAO, 2010; Zhang et al., 2002). However, land and market policies will have to be revised and employed to encourage agricultural intensification and promote allocation of spared land to alternative uses which sequester more carbon and/or emits fewer GHGs. Institutional-tenure issues and land-use sustainable development must be part of the comprehensive strategy for this to be effective greenhouse gas mitigation strategy (Sonwa et al., 2011; Venema \& Rehman, 2007; Dobbs \& Pretty, 2004; Rojas \& Aylward, 2003).

Countries in the subregion revising their agricultural policy architecture must ensure that adequate land and water management is central to the performance of the sector. This will require that in the management of agricultural land the following must be observed:

- Developing sustainable land management through improved land tenure systems and community natural resources management (Duguma et al., 2001).

- $\quad$ Preserving and enhancing the productive capabilities of land in cropped and grazed areas, e.g. upland areas, down slope areas, and flat and bottom lands (Robiglio et al., 2010).

- $\quad$ Taking actions to stop and reverse degradation - or at least to mitigate the adverse effects of earlier misuse - whether in the uplands and watersheds (Geist \& Lambin, 2002).

- $\quad$ Reducing soil manipulation to maximize vegetative cover to reduce soil erosion, restore organic matter, and conserve soil moisture and soil fertility (Buresh \& Tian, 1998; Kotto-Same et al., 1997).

- Correct for gender related issues with special attention to access to land for women and marginalized groups (Agarwal, 2009, Arora-Jonsson, 2011).

- $\quad$ Establish a land policy through a participatory process with adequate regulations, good governance in land administration and secured land rights aimed at sustaining agroforestry systems (Vignola et al., 2009). According to Swallow et al. (2005), secure property rights are often seen as a necessary pre-condition for carbon sequestration arrangements. On the other hand, environmental services can influence property rights. The type of environmental service, and the possibility of exclusion it provides, is also likely to influence the type of property rights.

- Mainstream climate change in national policies and regulations, and promote appropriate adaptation mechanisms in regional land management cooperation frameworks (Campbell, 2009; Clemençon, 2008; Goklany, 2007).

Policy makers in the CBF, conscious of the inherent opportunities to better exploit their agroecology could take advantage of some initiatives, described in Table 2, being developed with the goal of building awareness of the importance of biodiversity within agriculture, to build capacity of farmers and to implement sustainable. Such initiatives in the table below will have to be promoted in the CBF. 
Table 2. Some sustainable agricultural initiatives

\begin{tabular}{ll}
\hline \multicolumn{1}{c}{ Agency } & \multicolumn{1}{c}{ Activity } \\
\hline Ecoagricultural partners & They work to understand the complex interactions between \\
http://www.ecoagriculture.org/index.php & $\begin{array}{l}\text { biodiversity, agricultural production, and rural livelihoods by } \\
\text { documenting and analyzing ecoagriculture cases, strategies and } \\
\text { outcomes. Help to build the capacity of 'innovators by linking } \\
\text { communities \& institutions worldwide, evaluate market models and } \\
\text { opportunities for ecoagriculture products and services, and analyze } \\
\text { and promote national and international policies to support the } \\
\text { development of ecoagriculture landscapes. }\end{array}$ \\
\hline
\end{tabular}

IFC Biodiversity \& Agricultural commodities programme

http://www.ifc.org/bacp
They aim to reduce the threats to biodiversity posed by agricultural expansion by leveraging market forces at all levels of the value chain. Help mainstream Better Management Practices (BMPs) focusing on palm oil, cocoa, sugarcane and soybeans.

\section{The Sustainable Agriculture Network} (SAN)

http://www.rainforest-alliance.org/

agriculture.cfm?id=san

Sustainable commodity initiative
(United Nations Conference on Trade
and Development and International
Institute for Sustainable Development)
http://www.sustainablecommodities.org/

UNCTAD BioTrade Initiative

http://www.biotrade.org/
This is a network of conservation groups that seek to transform the environmental and social conditions of tropical agriculture through the implementation of sustainable farming practices. Commencing work on standards for sustainable cattle ranching.

This seeks to build effectiveness across voluntary approaches to sustainable commodity production and trade by promoting good governance, impact analysis, information exchange as well as policy and initiative development.

Promotes sustainable biotrade in support of the objectives of the Convention on Biological Diversity. Has a range of regional programmes with defined principles and criteria for goods and services derived from native biodiversity based on the objectives of the CBD.

\begin{tabular}{ll}
\hline Sustainable Food Laboratory & $\begin{array}{l}\text { Seeks to accelerate the production of sustainable food by facilitating } \\
\text { http://www.sustainablefoodlab.org/ }\end{array}$ \\
& $\begin{array}{l}\text { and water, etc., that are necessary for a healthy and sustainable food } \\
\text { system to feed a growing world. }\end{array}$ \\
\hline
\end{tabular}

\section{Conclusion}

Agriculture is a sine qua non for the socio-economic development in the Congo Basin. Large parts of the region have the potential of adequate rainfall and substantial water resources. Yet some challenges exist that constrain the exploitation and proper development of its agricultural potential and has enshrined significant pockets of food insecurity. It is now recognized that these problems are surmountable. However, business as usual in agricultural management, especially land and water management or marketing of agricultural produce, is not the way to overcome them. With increasing pressure on the CBF, it is important to employ a package of measures which is uniquely suited to address the key issues of the region such as: enriching the asset base of poor household; maximizing the productivity of farming system to help improve the productivity of crops and livestock; improving the income of poor households by better linking them to markets; expanding the multi-functionality of forest landscapes by balancing increased productivity with the sustainable management of the natural resources; and enhancing the supply ecosystems services in agricultural landscapes. The model prescriptions are to achieve these objectives and to stimulate a shift in approach towards sustainable development of the region's agriculture for poverty alleviation, socioeconomic development and environmental welfare. These prescriptions should assist in the mobilization of political will, regional support and sustainable financial resources to make the vision of food security and better welfare a reality in the sub-region. 


\section{Acknowledgements}

The authors are grateful to colleagues at the FAO and the reviewers for helpful comments on earlier versions of this paper. The views expressed in this research are those of the authors and do not necessarily reflect the views or policies of the FAO, or any other organization where the authors work.

\section{References}

Agarwal, B. (2009). Gender and forest conservation: The impact of women's participation in community forest governance. Ecological Economics, 68, 2785-2799. http://dx.doi.org/10.1016/j.ecolecon.2009.04.025

Ajayi, O. C., Place, F., Akinnifesi, F. K., \& Sileshi, G. W. (2011). Fertilizer tree systems in Southern Africa (Malawi, Tanzania, Mozambique, Zambia and Zimbabwe). International Journal of Agricultural Sustainability, 9(1), 129-136. http://dx.doi.org/10.3763/ijas.2010.0554

Arora-Jonsson, S. (2011). Virtue and vulnerability: Discourses on women, gender and climate change. Global Environmental Change, 21(2), 744-751. http://dx.doi.org/10.1016/j.gloenvcha.2011.01.005

Asaah, E. K., Tchoundjeu, Z., Leakey, R. R. B., Takousting, B., Njong, J., \& Edang, I. (2011). Trees, agroforestry and multifunctional agriculture in Cameroon. International Journal of Agricultural Sustainability, 9(1), 110-119. http://dx.doi.org/10.3763/ijas.2010.0553

AU. (2006). Declaration of the Abuja Food Security Summit on Food Security in Africa, 4-7 December 2006, Abuja, Nigeria.

Awono, A., Ndoye, O., \& Preece, L. (2010). Empowering women's capacity for improved livelihoods in nontimber forest product trade in Cameroon, International Journal of Social Forestry, 3(2), 151-163.

Bellassen, V., \& Glitz, V. (2008). Reducing emissions from deforestation and degradation in Cameroon-assessing costs and benefits. Ecological Economics, 68(2), 336-344. http://dx.doi.org/10.1016/j.ecolecon.2008.03.015

Bonan, G. B. (2008). Forests and climate change: forcings, feedbacks, and the climate benefits of forests. Science, 320, 1444-1449. http://dx.doi.org/10.1126/science.1155121

Buresh, R. J., \& Tian, G. (1998). Soil improvement by trees in sub-Saharan Africa. Agroforestry Systems, 38(2), 51-76.

Brown, P. H. C. (2011). Gender, climate change and REDD+ in the Congo Basin forests of Central Africa. International Forestry Review, 13(2), 163-176. http://dx.doi.org/10.1505/146554811797406651

Brown, K., \& Corbera, E. (2003). Exploring equity and sustainable development in the new carbon economy. Climate Policy, 3, 41-56. http://dx.doi.org/10.1016/j.clipol.2003.10.004

Brown, K., \& Lapuyade, S. (2001). A livelihood from the forest: Gendered visions of social, economic and environmental change in Southern Cameroon. Journal of International Development, 13, 1131-1149. http://dx.doi.org/10.1002/jid.802

Brummett, R. E., \& Jamu, D. M. (2011). From researcher to farmer: partnerships in integrated aquaculture-agriculture systems in Malawi, Ghana and Cameroon. International Journal of Agricultural Sustainability, 9(1), 282-289. http://dx.doi.org/10.3763/ijas.2010.0570

Bryan, E., Akpalu, W., Yesuf, M., \& Ringler, C. (2008). Global Carbon Markets: Are There Opportunities for Sub-Saharan Africa? IFPRI Discussion Paper 00832 - International Food Policy Research Institute, Washington, D.C., USA.

Butler, R. A. (2011). Saving rainforests through sustainable development—agriculture. Retrieved August 19, 2011, From http://rainforests.mongabay.com/1002.htm

Campbell, B. M. (2009). Beyond Copenhagen: REDD+, agriculture, adaptation strategies and poverty. Global Environmental Change, 19, 397-399. http://dx.doi.org/10.1016/j.gloenvcha.2009.07.010

Canadell, J. G., \& Raupach, M. R. (2008). Managing forests for climate change mitigation. Science, 320, 1456-1457.

Clemençon, R. (2008). The Bali road map: A first step on the difficult journey to a post-Kyoto protocol agreement. The Journal of Environment and Development, 17(1), 70-94. http://dx.doi.org/10.1177/1070496508314223 
de Wasseige, C., Devers, D., de Marcken, P., Eba'a Atyi, R., Nasi, R., \& Mayaux, Ph. (2009). The Forests of the Congo basin - State of the Forest 2008. Luxembourg: Publications Office of the European Union.

Donald, P. F. (2004). Biodiversity impacts of some agricultural commodity production systems. Conservation Biology, 18(1), 17-37. http://dx.doi.org/10.1111/j.1523-1739.2004.01803.x

Duguma, B., Gockowski, J., \& Bakala, J. (2001). Smallholder Cacao (Theobroma cacao Linn.) cultivation in agroforestry systems of West and Central Africa: challenges and opportunities. Agroforestry Systems, 51(3), 177-188. http://dx.doi.org/10.1023/A:1010747224249

Dupraz, C., Burgess, P., Gavaland, A., Graves, A., Herzog, F., Incoll, L., ... Werf Van der, W. (2005). Synthesis of the Silvoarable Agroforestry for Europe project. Montpellier: INRA-UMR System Editions, p. 254. Retrieved from http://www.ensam.inra.fr/safe/

Duveiller, G., Defourny, P., Descle'e, B., \& Mayaux, P. (2008). Deforestation in Central Africa: estimates at regional, national and landscape levels by advanced processing of systematically-distributed Landsat extracts, Remote Sens Environ, 112(5), 1969-1981. http://dx.doi.org/10.1016/j.rse.2007.07.026

EcoAgriculture Partners, Rights and Resources Initiative, World Agro-forestry Centre. (2011). Making REAL(U) right: harmonizing agriculture, forests and rights in the design of REDD+. Retrieved from www.asb.cgiar.org/PDFwebdocs/Making\%20REALU\%20right.pdf

Ezzine de Blas, D., Ruiz Pe'rez, J. A., Sayer, G., Lescuyer, R., \& Karsenty, A. (2009). 'External influences on and conditions for community logging management in Cameroon, World Development, 35(2), 445-456. http://dx.doi.org/10.1016/j.worlddev.2008.03.011

FAO. (2009). Enhancing Crop-Livestock Systems in Conservation Agriculture for Sustainable Production Intensification: A Farmer Discovery Process Going to Scale in Burkina Faso. Integrated Crop Management 7, Food and Agriculture Organization of the United Nations, Rome, Rome.

FAO. (2010). Climate Change and its Effect on Conservation and Use of Plant Genetic Resources for Food and Agriculture and Associated Biodiversity for Food Security, Background Study Paper No. 52, Food and Agriculture Organization of the United Nations, Rome.

FAO. (2010). Climate-smart agriculture: policies, practices and financing for food security, adaptation and mitigation. $\quad$ Rome: FAO. $\quad$ Retrieved http://www.fao.org/fileadmin/user_upload/newsroom/docs/the-hague-conference-fao-paper.pdf

FAO. (2011). The State of Forests in the Amazon Basin, Congo Basin and Southeast Asia. A report prepared for the Summit of the Three Rainforest Basins, Brazzaville, Republic of Congo, 31 May-3 June, 2011. Food and Agricultural Organisation of the United Nations of the United Nations, Rome.

FAO. (2012). Forest Management and Climate Change: a literature review, Forests and Climate Change Working Paper 10, Food and Agriculture Organization of the United Nations, Rome.

Feddema, J. J., Oleson, K. W., Bonan, G. B., Mearns, L. O., Buja, L. E., Meehl, G. A., \& Washington, W. M. (2005). The importance of land-cover change in simulating future climates. Science, 310, 1674-1678. http://dx.doi.org/10.1126/science.1118160

Geist, H. J., \& Lambin, E. F. (2002). Proximate Causes and Underlying Driving Forces of Tropical Deforestation. Bioscience, 52.

Giller, K., Mazwita, E., Murwira, S., David, K., Dhliwayo, C., Paramu, L., .. Mpepereki, S. (2011). Soyabeans and sustainable agriculture in southern Africa. International Journal of Agricultural Sustainability, 9(1), 50-58. http://dx.doi.org/10.3763/ijas.2010.0548

Goklany, I. (2007). Integrated strategies to reduce vulnerability and advance adaptation, mitigation, and sustainable development. Mitigation and Adaptation Strategies for Global Change, 12, 755-786. http://dx.doi.org/10.1007/s11027-007-9098-1

Harvey, C. A., Dickson, B., \& Kormos, C. (2010). Opportunities for achieving biodiversity conservation through REDD. Conserv Lettm, 3, 53-61. http://dx.doi.org/10.1111/j.1755-263X.2009.00086.x

ICRAF. (2002a). Alternatives to slash and burn: summary report and synthesis of phase II in Indonesia. Nairobi: ICRAF.

ICRAF, (2002b). Alternatives to slash and burn: summary report and synthesis of phase II in Cameroon. Nairobi: ICRAF. 
Intergovernmental Panel on Climate Change (IPCC). (2007). Climate Change 2007: Synthesis Report. Cambridge, Cambridge University Press.

Joly, C. A. (2010). The changes proposed in the Brazilian Forest Code do not have scientific support. Biota Neotropica, 10(4), 1.

Justice, C., Wilkie, D., Zhang, Q., Brunner, J., \& Donoghue, C. (2001). Central African forests, carbon and climate change. Climate Research, 17, 229-246. http://dx.doi.org/10.3354/cr017229

Kassam, A., Friedrich, T., Shaxson, F., \& Pretty, J. (2009). The spread of conservation agriculture: justification, sustainability and uptake. International Journal of Agricultural Sustainability, 7(4), 292-320. http://dx.doi.org/10.3763/ijas.2009.0477

Koohafkan P., Altieri, M. A., \& Gimenez, E. H. (2012). Green Agriculture: foundations for biodiverse, resilient and productive agricultural systems. International Journal of Agricultural Sustainability, 10(1), 61-75. http://dx.doi.org/10.1080/14735903.2011.610206

Kotto-Same J. P. Woomer, L. M., Appolinaire, M., \& Zapfack, L. (1997). Carbon dynamics in slash and burn agriculture and land use alternatives in the humid forest zone of Cameroon. Agric Ecosyst Environ, 65, 245-256. http://dx.doi.org/10.1016/S0167-8809(97)00060-1

Kamdem-Toham, A., Adeleke, W., Burgess, N. D., Carroll, R., D’Amico, J., Dinerstein, E., ... Some, L. (2003). Forest conservation in the Congo Basin. Science, 299, 346. http://dx.doi.org/10.1126/science.299.5605.346

Kristjanson, P., Reid, R. S., Dickson, N., Clark, W. C., Romney, D., Puskur, R., ... Grace, D. (2009). Linking international agricultural research knowledge with action for sustainable development. Proceedings of the National Academy of Sciences, 106, 5047-5052. http://dx.doi.org/10.1073/pnas.0807414106

Liebenehm, S., Affognon, H., \& Waibel, H. (2011). Collective livestock research for sustainable disease management in Mali and Burkina Faso. International Journal of Agricultural Sustainability, 9(1), 212-221. http://dx.doi.org/10.3763/ijas.2010.0572

Lewis, J., Vosti, S., Witcover, J., Ericksen, P. J., Guevara, R., \& Tomich T. (2002). Alternatives to slash and burn: summary report and synthesis of phase II in Brazil. Nairobi: ICRAF.

Marongwe, L. S., Karsto, K., Michael, J., Christian, T., Amir, K., \& Friedrich, T. (2011). An African success: the case of conservation agriculture in Zimbabwe. International Journal of Agricultural Sustainability, 9(1), 153-161. http://dx.doi.org/10.3763/ijas.2010.0556

Matthews, S., Connor, R. O., \& Plantinga, A. J. (2002). Quantifying the impacts on biodiversity of policies for $\begin{array}{lllll}\text { carbon sequestration in forests, Ecological Economics, 4, } & \text { 71-78. }\end{array}$ http://dx.doi.org/10.1016/S0921-8009(01)00269-5

Mpepereki, S., Javaheri, F., Davis, P., \& Giller, K. E. (2000). Soyabeans and sustainable agriculture: "Promiscuous" soyabeans in southern Africa. Field Crops Research, 65, 137-149. http://dx.doi.org/10.1016/S0378-4290(99)00083-0

Ndoye, O., \& Kaimowitz, D. (2000). Macro-economics, markets and the humid forest of Cameroon, 1967-1997. J Mod Afr Stud, 38(2), 225-253. http://dx.doi.org/10.1017/S0022278X00003347

Nelson, G. C., Rosegrant, M. W., Palazzo, A., I. Gray, C., Ingersoll, R., Robertson, S., ... You, L. (2010). Food security, farming, and climate change to 2050: scenarios, results, policy options. Washington, DC: International Food Policy Research Institute.

Nkem, J. N., Kalame, F. B., Idinoba, M., Somorin, O. A., Ndoye, O., \& Awono, A. (2010). Shaping forest safety nets with markets: Adaptation to climate change under changing roles of tropical forests in Congo Basin. Environmental Science \& Policy, 13, 498-508. http://dx.doi.org/10.1016/j.envsci.2010.06.004

Owenya, M. Z., Wilfred L. Mariki, Josef, K., Theodor, F., \& Kassam, A. (2011). Conservation agriculture (CA) in Tanzania: the case of the Mwangaza B CA farmer field school (FFS), Rhotia Village, Karatu District,

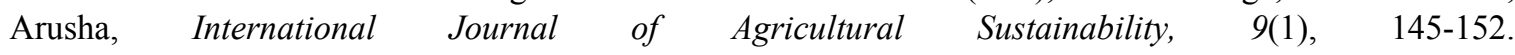
http://dx.doi.org/10.3763/ijas.2010.0557

Peltier R, Bisiaux, F., Dubiez, E., Marien, J. N., Muliele, J. C., Proces, P., \& Vermeulen, C. (2010). De la culture itinérante sur brûlis aux jachères enrichies productrices de charbon de bois, en Rep. Dem. Congo. Retrieved from http://www.mampu.org 
Pretty, J., Toulmin, C., \& Williams, S. (2011). Sustainable intensification in African agriculture. International Journal of Agricultural Sustainability, 9(1), 5-24. http://dx.doi.org/10.3763/ijas.2010.0583

Ravindranath, N. H. (2007). Adaptation and Mitigation synergy in the forest sector. Adaptation and Mitigation Strategies for Global Change, 12, 843-853. http://dx.doi.org/10.1007/s11027-007-9102-9

Robiglio, V., Ngendakumana, S., Gockowski, J., Yemefack, M., Tchienkoua, M., Tchawa, P., Tchoundjeu, Z., \& Bolognesi, M. (2010). Reducing Emissions from All Land Uses in Cameroon. Final National Report. Nairobi: ASB Partnership for the Tropical Forest Margins. Retrieved from www.asb.cgiar.org/PDFwebdocs/CAMEROON\%20REALU.pdf

Sawadogo, H. (2011). Using soil and water conservation techniques to rehabilitate degraded lands in northwestern Burkina Faso. International Journal of Agricultural Sustainability, 9(1), 120-128. http://dx.doi.org/10.3763/ijas.2010.0552

Schroth, G., A.Gustavo, B., DaFonseca, C. A., Harvey, C., Gascon, H., Vasconcelos, L., \& Izac, A. M. N. (2004). Agroforestry and Biodiversity Conservation in Tropical Landscapes. Washington, DC: Island Press.

Settle, W., \& Garba, M. H. (2011). Sustainable crop production intensification in the Senegal and Niger River basins of francophone West Africa. International Journal of Agricultural Sustainability, 9(1), 171-185. http://dx.doi.org/10.3763/ijas.2010.0559

Sileshi, G., Akinnifesi, F. K., Ajayi, O. C., \& Place, F. (2008). Meta-analysis of maize yield response to planted fallow and green manure legumes in sub-Saharan Africa. Plant and Soil, 307, 1-19. http://dx.doi.org/10.1007/s11104-008-9547-y

Silici, L., Ndabe, P., Friedrich, T., \& Kassam, A. (2011). Harnessing sustainability, resilience and productivity through conservation agriculture: the case of likoti in Lesotho. International Journal of Agricultural Sustainability, 9(1), 137-144. http://dx.doi.org/10.3763/ijas.2010.0555

Sonwa, D. J., Walker, S., Nasi, R., \& Kanninen, M. (2011). Potential synergies of the main current forestry efforts and climate change mitigation in Central Africa. Sustainability Science, 6, 59-67. http://dx.doi.org/10.1007/s11625-010-0119-8

Styger, E., Aboubacrine, G., Attaher, M. A., \& Uphoff, N. (2011). The system of rice intensification as a sustainable agricultural innovation: introducing, adapting and scaling up a system of rice intensification practices in the Timbuktu region of Mali. International Journal of Agricultural Sustainability, 9(1), 67-75. http://dx.doi.org/10.3763/ijas.2010.0549

Swallow, B., Meinzen-Dick, R. S., \& Noordwijk, M. V. (2005). Localizing demand and supply of environmental services: Interaction with property rights, collective action, and the welfare of the poor. CAPRi Working Paper 42. Washington DC: IFPRI. http://www.capri.cgiar.org/pdf/capriwp42.pdf

Thiombiano, L., Molua E. L., Sankung, S., Jean, C. N., \& Fonteh, M. (2012). Conceptual Structure for Climate-Smart Agriculture for enhanced Productivity in the Congo Basin. Nature \& Faune, 26(2), 28-32.

Thornton, P. K., Jones, P. G., Ericksen, P. J., \& Challinor, A. J. (2011). Agriculture and food systems in sub-Saharan in a $4^{\circ} \mathrm{C}+$ world, Phil. Trans. R. Soc. A, 369, 117-136. http://dx.doi.org/10.1098/rsta.2010.0246

Toulmin, C. (2009). Climate Change in Africa. London, Zed Books.

UNEP. (2007). Fourth Global Environment Outlook: Environment for Development Section B: State-And-Trends of the Environment 1987-2007; Chapter 5: Biodiversity. http://www.unep.org/geo/geo4/report/05_Biodiversity.pdf

USDA. (2010). Riparian forest buffer: conservation reserve enhancement program-CPEP-CP22. Natural $\begin{array}{lllll}\text { Resources Conservation } & \text { Service } & \text { (NRCS). } & \text { Retrieved }\end{array}$ http://www.ia.nrcs.usda.gov/technical/JobSheet/riparian.pdf

Valentin, C., Rajot, J. L., \& Mitja, D. (2002). Responses on soil crusting runoff and erosion to fallowing in the sub-humid and semi-arid regions of West Africa. Agriculture, Ecosystem and Environment, 3, 56-69.

Vignola, R., Locatelli, B., Martinez, C., \& Imbach, P. (2009). Ecosystem-based adaptation to climate change: what role for policy-makers, society and scientists? Mitigation and Adaptation Strategies for Global Change, 14, 691-696. http://dx.doi.org/10.1007/s11027-009-9193-6 
Wambugu, C., Frank, P., \& Franzel, S. (2011). Research, development and scaling-up the adoption of fodder shrub innovations in East Africa. International Journal of Agricultural Sustainability, 9(1), 100-109. http://dx.doi.org/10.3763/ijas.2010.0562

Yerima, B. P. K. (2011). Protective measures taken for preserving species endangered of extinction due to the climate change in sub-Sahara Africa: Case of the Yongka Western Highlands Research Garden-Park, Nkwen - Bamenda, North West Region, Cameroon (pp. 4-11). Research and Development in Sub-Saharan Africa.

Zhang Q., Justice, C. O., \& Desanker, P. V. (2002). Impacts of simulated shifting cultivation on deforestation and carbon stocks of the forests of central Africa. Agric Ecosyst Environ, 90, 203-209. http://dx.doi.org/10.1016/S0167-8809(01)00332-2

\section{Notes}

Note 1. An incentive mechanism developed in the Bali Action Plan under the United Nations Framework Convention on Climate Change, is intended to create financial incentives to keep forests intact and manage them more sustainably (Clemençon, 2008). Under the mechanism, Annex 1 countries (developed or industrialized countries) would compensate developing countries for reducing deforestation and forest degradation. In addition, the Bali Action Plan calls for positive incentives for conservation activities, the sustainable management of forests, and the enhancement of forest carbon stocks, collectively known as "REDD+".

Note 2. Forest play a very important role in the hydrological cycle as their presence or absence affects the runoff and amount of infiltration. These in turn have an impact on erosion, the flow of rivers, water quality and sedimentation of reservoirs.

Note 3. In addition to the trees, the overall biomass of forests also acts as a "carbon-sink" or carbon store (Zhang et al., 2002).

Note 4. FAO (2010) defines agroforestry as the use of trees and shrubs in agricultural crop and/or animal production and land management systems. Trees are used in many traditional and modern farming and rangeland systems. Agroforestry systems and practices may include improved fallows, growing annual agricultural crops during the establishment of a forest plantation, home gardens, growing multipurpose trees and shrubs, farm woodlots, orchards, plantation/crop combinations, shelterbelts, windbreaks, conservation hedges, fodder banks, live fences, trees on pasture and tree apiculture.

Note 5. Such research may focus but not limited to crop and livestock production, water availability and access, including adaptation to climate change. It may also include how land and water are used and how they can be used more productively; and their relationship to the environment. Also important is multidisciplinary socioeconomic research in understanding land-use changes on emissions and implications of incentives for agriculture in forest areas.

\section{Copyrights}

Copyright for this article is retained by the author(s), with first publication rights granted to the journal.

This is an open-access article distributed under the terms and conditions of the Creative Commons Attribution license (http://creativecommons.org/licenses/by/3.0/). 